ment and symbol of America's industrial success, auto makers and their workers have suffered severe setbacks as production, consumption, and competition on an international scale have displaced the U.S. monopoly on its own market. Given the circumstances, this industry may be less susceptible to meaningful union intervention than some others that retain strong local or national orientations.

Furthermore, the conference seemed to lose sight of the concept of democracy itself, substituting the issue of control in the factory for larger questions. Certainly unions have continued to discuss democracy, and it would have been useful to trade some of the changing meanings and political compromises involved in their activities. But finally, the conference, by anchoring itself in the optimistic notion of industrial democracy, may simply have underscored, as Robert Wiebe (Northwestern) noted in his closing comments, that organized labor's real power in twentieth-century America has been glorious, but short-lived.

\title{
Fifth Annual Latin American Labor History Conference
}

\author{
John D. French \\ Florida International University
}

The Fifth Annual Latin American Labor History Conference was held 22-23 April 1988 at Princeton University, with the generous support of the Wallace Fund and the Office of the Dean of Students, the Latin American Studies Program, the Woodrow Wilson School, and the Princeton Department of History. The conference focused on the difficult challenge of incorporating racial, ethnic, and community identities into a new and broader conception of social class.

In "Sabana City and Valley Town: The Democratic Societies of Bogotá and Cali, Columbia, 1847-1854," David Sowell (South Carolina) examined urban artisanal and middle-sector political participation in two very different regional contexts. Sowell argued that possession of the privilege of political participation made these groups significant political and social brokers in the postindependence era. Under the newly established republican system, he observed, elite competition created significant openings for previously unarticulated social and economic discontent. The popular interests that were expressed through the Democratic Societies varied in each city, as did their degree of success. Serious analysis of the activities and identities of these non-elite groups, Sowell concluded, can contribute to a rethinking of Latin American political culture in the early national period.

Michael Jiménez (Princeton) noted that Sowell's paper examined the learning curve of republican politics as former outsiders were incorporated into citizenship. To explain the diverging outcomes in Cali and Bogotá, Jiménez suggested, 
requires a fuller treatment of the political economy, elite strategies, and the differing resources and consciousness of the lower classes in the two regions. Emilia Viotti da Costa (Yale) praised Sowell for taking these Latin American "sans-culottes" seriously after many years of neglect by other scholars. Speaking of the Brazilian case, she noted that artisans elaborated a significant independent project as they confronted the destructive pressures of nineteenth-century free trade. Da Costa ended by calling for a systematic comparative analysis of artisan radicalism throughout Latin American in this period.

In the thirty years covered by George Reid Andrews's "Black Workers and White: São Paulo, Brazil, 1888-1928" (see Hispanic American Historical Review [August 1988]), São Paulo underwent a radical transition from plantation slavery to an immigrant tenantry. During those years, a modern industrial society also emerged in the cities. What happens to ex-slaves, Andrews (Pittsburgh) asked, in such a rapidly modernizing society? What replaces the earlier paternalistic system of race relations as a more competitive capitalist system emerges? And what leads an emerging labor movement to reject or embrace a racially exclusive strategy of working-class organization? Andrews convincingly rejected the sociopsychological and cultural explanations advanced by Florestan Fernandes to explain why exslaves were pushed out of São Paulo labor markets by immigrants. Instead, he emphasized how the government/planter policy of flooding the labor market with immigrants after emancipation was fraught with negative "racial implications" for blacks.

In his comments, Magnus Morner (Gothenburg) challenged Andrews's bold advocacy of a North American biracial approach to race relations in Brazil. In contrast, Morner argued for "a fundamental difference between the U.S. biracial descent-based pattern of race relations and the complex and subtle multiracial Brazilian pattern." He also raised questions about the differences among nonwhites (between slaves and freed blacks, between mulattos and blacks, and between largely black ex-slaves and dark complexioned agregados and caipiras). The paulista reality, he suggested, included a more "complex system of strategies on the part of both the powerful native white group and on the part of those discriminated against." He ended by noting the relevance of Parkin's notion of dual closure - upwards and downwards - and of the recent literature on segmented or split labor markets.

Focusing on the urban labor issues posed by Andrews, John D. French (Florida International) doubted whether the paulista labor movement in these years was strong enough to even think of structuring the labor market on its own terms - whether in a racially exclusive or inclusive manner. After questioning the depth of the alleged nonracialism of São Paulo's immigrant labor leaders, French argued that the marginal participation of non-whites in industry might be better explained through immigrant traditions of ethnic solidarity that produced discriminatory policies among immigrant entrepreneurs in the cities.

Both Andrews and Sowell, Jiménez noted, dealt with the ambivalent relation- 
ship between ethnicity/race and capitalism: what happens when coercive labor markets come undone and yet modalities of the earlier system such as race continue to be used. In the ensuing discussion, Andrews defended his black/white division as corresponding to observable structural outcomes that can be demonstrated from census and household survey data in 1960, 1976, and 1980. Citing the inherent difficulty of achieving the levels of complexity demanded by Morner, Andrews discussed the problems he had faced in establishing a consistent racial classification system in analyzing employment records in São Paulo.

In "The Italian Mutual Aid Societies of Buenos Aires: Issues of Class and Ethnicity within an Immigrant Community, 1858-1920," Romolo Gandolfo (Yale) criticized the consensus position that sees ethnicity as a folkloric and inconsequential appendage to the history of the Argentine working class. "Unless and until we bring ethnicity to the center," Gandolfo argued, "we will inevitably continue to miss the complexity and the richness of Argentine labor history."

Possessing over fifty thousand members in fifty different organizations, Gandolfo argued that "broad based multi-class mutual aid societies" were a pervasive aspect of Italian immigrant life. Although overwhelmingly composed of manual workers, the leadership of such societies was just as exclusively held by non-workers. Yet the shared ideal of ethnic solidarity, Gandolfo argued, only masked the "diffused, structural intra-ethnic conflict" that permeated community life. Examining strikes and landlord/tenant conflicts pitting Italians against Italians, he found that both sides consistently denied the intra-ethnic dimension of such disputes. The difficulty of openly articulating class and ethnic issues resulted, he concluded, in the coexistence of ethnicity and a cosmopolitan labor unionism in a "complex, if unexplored, relationship of complementarity and competition."

In an encyclopedic paper, "Class and Ethnicity: The Jewish Labor Movement in Buenos Aires, 1900-1930," Edgardo Bilsky (Institut des Hautes Etudes d'Amerique Latine, University of Paris) examined the construction of a Jewish workers' movement in Buenos Aires. After examining living and working conditons, Bilsky discussed the simultaneous creation of a Jewish urban ethnic space and an ethnic class subculture within the community. Finding both integrationist and ethnocentric perspectives vis-a-vis the wider society, Bilsky explored the Jewish workers' struggle for hegemony within the Jewish community and its fight for legitimacy within the wider Argentine labor movement.

Both Gandolfo and Bilsky, Samuel L. Baily (Rutgers) commented, made ethnicity central to their approach to the history of labor, which is an encouraging sign of dialogue between fields of scholarly research that are too often dealt with separately. Calling for further consideration of the Old World background, Baily noted that both papers treated the immigrant as a total person fully capable of sustaining various identities. Suggesting broader comparisons to establish uniqueness or commonality, Baily queried Gandolfo as to whether all mutual aid societies necessarily diffuse class conflict at all times. And if not, what factors cause 
ethnicity to work against class consciousness at some points and to strengthen it at others.

Gandolfo and Bilsky, Steve Stein (Miami) observed, see ethnicity quite properly as a potentially unifying and simultaneously divisive force within a horizontal multi-ethnic reality. Yet when, and under what conditions, he asked, does a positive self-identity for one group imply a negative image of others? $\mathrm{Da}$ Costa saw evidence of progress towards a new vision of class as something constructed and not as a given. Arguing for a sharper delineation of the differences between ethnicity, nationality, and race, she noted that the impact of gender was absent from these discussions of ethnicity. Prevailing notions of class, da Costa argued, have tended to ignore or downplay race or ethnicity (along with gender) out of a belief that class has obliterated these distinctions. Scholars should further explore the phenomenon of multiple identities articulated by individuals and groups in different ways and with different weights at different times, she argued.

In "Class, Ethnicity, and Agrarian Conflict in Subtiava, Nicaragua," Jeffrey Gould (Indiana) explored the survival of an "Indian" ethnic identity among the Subtiava in mestizo Nicaragua. Although Indians comprised 40 percent of the population in 1900 , the succeeding decades saw government action to eliminate Indians as an identifiable ethnic community and the simultaneous decline of Indianness as a source of group identity. Although the Subtiava are indistinguishable from ladinos in physical appearance, language, dress, and customs, the group's indigenous identity has been preserved through the parcialidade, an endogamous kinship unit, and by their mastery of the dialectic of class and ethnicity as they resisted racism and capitalist expansion.

In his comments, Jiménez praised Gould's richness of detail and the dramatic heroism of survival against the odds. Yet he questioned whether the Subtiava's struggle had not been transformed between the 1920s and the era of the Sandinista Revolution in 1979. Calling for greater attention to internal differentiation, Jiménez asked why the Subtiava survived, unlike thousands of other Nicaraguan Indians. In reply, Gould noted that the Subtiava's view of themselves as Indians is not only real at the subjective level, but may be even stronger precisely because their self-definition as Indians is all that remains of their earlier identity.

Noting that discussion of gender, unlike race, has grown in contemporary Cuba, Lois Smith and Alfred Padula (Southern Maine) explored the current debate over the working and living conditions of Cuban women. Based on surprisingly frank discussions since 1986, "Public Employment in Accordance with Physiological and Social Laws: Women and Labor in Socialist Cuba" provided a detailed portrayal of the contradictions and conflicts between different institutions, organizations, administrators, and individuals over the issues attendant to women's employment. After tracing the rapid rise in women's work force participation since 1959, they explored the issue of women's double burden, the moral double standard, the problem of reproduction, the abuse of existing laws to restrict female workers, and women's own self-limitation in the work world. 
Daniel James (Yale) discerned a certain state-centered focus to the analysis, and asked how the women's question related to the broader issue of political participation and power in contemporary Cuba. James and Jiménez both called for greater attention to the distinctions among the working women being discussedsuch as the differences between urban and rural or middle- and working-class women. Peter Winn (Tufts) amplified on these comments and suggested the need for more of an internal analysis from below. Winn also pointed out that the comments of Cuban women's leader Vilma Espin were remarkably critical and would have been unheard of ten years ago. Is it Fidel Castro's support that makes this possible, he asked, to which Smith responded by citing the oft-cited comment that Fidel may in fact be Cuba's top feminist.

The explosion of interest in Latin American labor history was amply proven by the growing interest in the conference and the boom in publications in this field. Moreover, the Latin American Studies Association has made labor a theme for its September 1989 meeting in San Juan, Puerto Rico. Plans are also advancing for a Latin American Labor Studies newsletter to be published jointly at Florida International University by the Latin American and Caribbean Center and the Center for Labor Research and Studies.

\title{
Labor, the Church, and Social Justice: The Fourteenth Annual Southwest Labor Conference
}

\author{
Bill Doyle \\ Coordinator, SWLSA '88
}

At the Fourteenth Annual Southwest Labor Conference, held at Loyola Marymount University, 29-30 April 1988, priests, nun, ministers, and lay religious activists met union and community organizers on their own grounds in half a dozen workshops, exchanging views and suggesting strategies to empower the working poor.

Loyola Marymount political science professor Bill Fitzgerald placed these struggles in perspective with an analysis of the pastoral letter on the economy by the U.S. Catholic Bishops. The Director of Work, Economics, and Religion (WER) reviewed WER's campaign to organize Chicana workers at a local toy factory; writer Pat Hoffman (Ministry of the Dispossessed, 1987) summed up some of the lessons learned by clergy who had joined the Farmworkers' grape boycott; and Catholic priests Gary Smith and John Seymour reported on their successful struggle in East Los Angeles to raise the minimum wage by action from both the state legislature and the archdiocese of Los Angeles.

Church activism also surfaced in the key plenary report by Eric Mann and 